\title{
Bacterial ecology of ancient Saharan salt-enrichment ponds at Teguidda-n-Tessoumt
}

\author{
Samuel Alvey ${ }^{1}$, Ching-Hong Yang ${ }^{2}$, Andreas Buerkert ${ }^{3 *}$, and David E. Crowley ${ }^{4}$ \\ 1 Department of Biology, Carroll College, 1601 North Benton Ave, Helena, MO 59625, USA \\ 2 Department of Plant Pathology, University of California Riverside, Riverside, CA 92521, USA \\ 3 Department of Organic Agriculture and Agroecosystems Research in the Tropics and Subtropics, University of Kassel, \\ D-37213 Witzenhausen, Germany \\ 4 Department of Environmental Sciences, University of California Riverside, Riverside, CA 92521, USA.
}

Accepted June 5, 2005

PNSS P05/20P

\section{Summary-Zusammenfassung}

Little is known about the bacterial ecology of evaporative saltmining sites (salterns) of which Teguidda-n-Tessoumt at the fringe of the West African Saharan desert in Niger is a spectacular example with its many-centuries-old and very colorful evaporation ponds. During the different enrichment steps of the salt produced as a widely traded feed supplement for cattle, animal manure is added to the crude brine, which is then desiccated and repeatedly crystallized. This study describes the dominant Bacteria and Archaea communities in the brine from the evaporation ponds and the soil from the mine, which were determined by PCR-DGGE of $16 \mathrm{~S}$ rDNA. Correspondence analysis of the DGGE-community fingerprints revealed a change in community structure of the brine samples during the sequential evaporation steps which was, however, unaffected by the brine's $\mathrm{pH}$ and electric conductivity (EC). The Archaea community was dominated by a phylogenetically diverse group of methanogens, while the Bacteria community was dominated by gamma proteobacteria. Microorganisms contained in the purified salt product have the potential to be broadly disseminated and are fed to livestock across the region. In this manner, the salt mines represent an intriguing example of long-term human activity that has contributed to the continual selection, cultivation, and dissemination of cosmopolitan microorganisms.

Key words: bacterial-community structure / DGGE fingerprinting / Niger

\section{Introduction}

For much of human civilization, microorganisms have been deliberately or inadvertantly enriched as a result of anthropogenic activities to process food, organic waste, and minerals. One such activity that combines all of the above is the production of salt, which in parts of West Africa is derived from salt-containing soils that are adjacent to oases in the Sahara desert. In ancient times, salt was an extremely valuable, widely traded commodity. To this day, salt produced at these mines, or salterns, continues to be transported by camel caravans across the Sahara and distributed throughout West Africa for use as an animal-feed supplement (Ajayi and Crowder, 1987; Buerkert and Hiernaux, 1998). Whereas there are

\footnotetext{
${ }^{*}$ Correspondence: Prof. Dr. A. Buerkert;

e-mail: buerkert@uni-kassel.de
}

\section{Die Mikroorganismenstruktur in Salzpfannen einer alten Saline in Teguidda-n-Tessoumt}

Über die Zusammensetzung von Mikroorganismen in Salinen der westafrikanischen Sahara ist bisher nur sehr wenig bekannt. Ein wegen seiner vielfarbigen Evaporationsbecken besonders spektakuläres Untersuchungsbeispiel ist die jahrhundertealte Saline Tegguida-n-Tessumt im Nordniger. Im Laufe des mehrere Konzentrationsstufen umfassenden Gewinnungsprozesses für das als Viehsalz weit gehandelte Endprodukt wird der Sole auch Tierdung zugemischt. Die hier vorgelegte Arbeit beschreibt die Struktur der vorherrschenden Bakterien und Archaea in der Sole aus den Evaporationsbecken sowie dem umgebenden Boden auf der Grundlage einer PCR-DGGE-Analyse der mikrobiellen 16S rDNA. Die Ergebnisse der Korrespondenzanalyse der DGGE-Fingerabdrücke zeigten eine deutliche Veränderung der mikrobiellen Zusammensetzung der Soleproben im Verlauf des Salzgewinnungsprozesses, die vom $\mathrm{pH}$-Wert und der elektrischen Leitfähigkeit (EC) der Sole unabhängig waren. Die Struktur der Archaea-Gemeinschaft wurde von einer phylogenetisch vielfältigen Gruppe von Methanogenen dominiert, wohingegen die Bakterien von Gamma-Proteobakterien beherrscht wurden. Die in dem Viehsalz enthaltenen Mikroorganismen können über Handel und tierische Futteraufnahme potenziell weit verbreitet werden. Vor diesem Hintergrund stellen die Salinen ein faszinierendes Beispiel dafür dar, wie menschliche Aktivität zur fortdauernden Selektion, Kultivierung und Verbreitung kosmopolitischer Mikroorganismen beitragen kann.

no written records about the exact establishment date of salt production at Teguidda-n-Tessoumt, Ajayi and Crowder (1987) reported its origin to go back at least to the 15th century. At this oasis, an elaborate salt-enrichment method has been devised, in which manure-mixed salty surface soil is placed into ponds from which the leached salts are extracted as a brine solution. The brine is then sequentially transferred to a three-stage series of evaporation ponds to obtain the final product (Fig. 1).

Ecologically, this saltern stands for a few unique, small areas in the Sahara desert, which through the combination of heavy-textured soil, a high groundwater table, and high salt concentrations in the soil led to extremely alkaline, saline environments. The study of microbial diversity in such unique environments may thus provide valuable information on microbial distribution and evolution and on the effects of anthropogenic activity on these processes. The underlying 


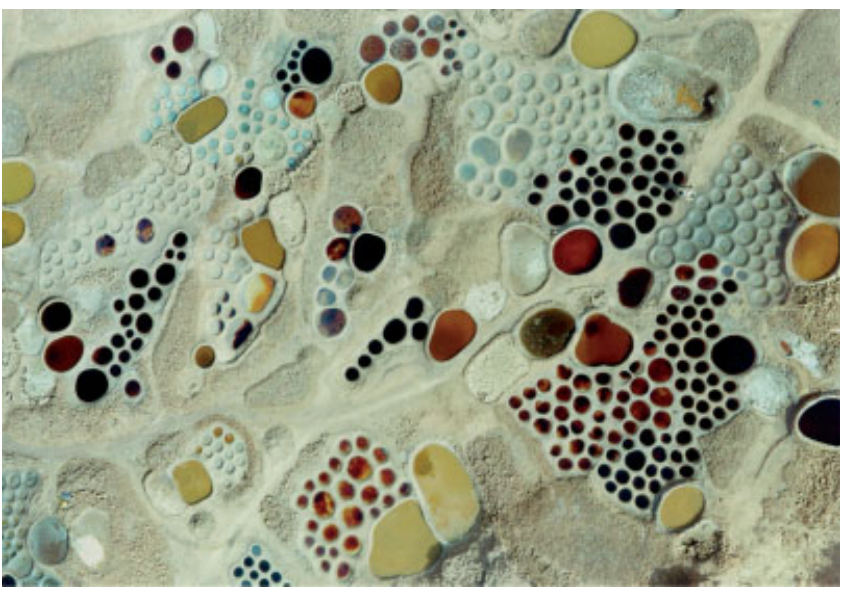

Figure 1: Aerial photograph of the evaporative salt-enrichment ponds at the Teguidda-n-Tessoumt salt mine, Niger, West Africa. The photograph was taken from $150 \mathrm{~m}$ height using a simple kite-based system (Buerkert et al., 1996).

Abbildung 1: Luftbildaufnahme der vielfarbigen Evaporationsbecken in der Saline Teguidda-n-Tessoumt im Norden des westafrikanischen Staates Niger. Die Aufnahme wurde aus $150 \mathrm{~m}$ Höhe mit einem einfachen Fesseldrachensystem erstellt (Buerkert et al., 1996).

hypothesis of this study was that the ecological setting of the salt evaporation ponds led to the creation of unique and yet diverse bacterial enrichment cultures that have been maintained there for hundreds of years.

\section{Materials and methods}

\subsection{Sampling}

To characterize the effects of the salt-enrichment process on the microbial community structure of the substrate, representative samples were taken in four replicates of (1) the leached-out soil material of different dumping sites within the about $250 \mathrm{~m}$ x $300 \mathrm{~m}$ sized saltern area, (2) the village surface soil near the mud buildings $(0-5 \mathrm{~cm}$ depth; $100-150 \mathrm{~m}$ from the saltern), and (3) a grassland soil with a very sparse cover of dry monocotyledons (0-5 cm depth) about $1 \mathrm{~km}$ from the Teguidda-n-Tessoumt saltern area in Niger, West Africa $\left(17^{\circ} 26^{\prime} \mathrm{N}, 6^{\circ} 38^{\prime} \mathrm{E}\right)$. In addition to these, four replicate brine samples were also taken from different ponds (sized 2-25 $\mathrm{m}^{2}$ ) in the saltern representing the three typical enrichment stages. All 24 samples were stored in plastic sample bags, frozen within $4 \mathrm{~h}$ of sampling and stored frozen until analysis when they were analyzed immediately after thawing. In brine samples, $\mathrm{pH}$ and electrical conductivity (EC) were measured directly, whereas in soils, the $\mathrm{pH}$ and $\mathrm{EC}$ measurements were made using 1:2 soil : water suspensions.

\subsection{DNA extraction}

Soil and brine samples containing $0.5 \mathrm{~g}$ soil, $0.5 \mathrm{~mL}$ brine, or a pellet from $20 \mathrm{~mL}$ brine centrifuged at $14,000 \mathrm{~g}$, were placed in a beadbeater tube (BIO 101, Vista, California, USA) and shaken in a Fastprep FP120 bead beater at $5.5 \mathrm{~m} \mathrm{~s}^{-1}$ for $30 \mathrm{~s}$. Total DNA from soil and brine samples was isolated with the Fast DNA Kit from BIO 101 as described by the manufacturer.

\subsection{PCR primers and DGGE analysis}

The PCR protocol was carried out as previously described (Yang and Crowley, 2000). Archaea communities were amplified using a nested PCR approach (Ovreas and Torsvik, 1998). Primers PRA46f and PREA1100r were used to produce a 1,072 bp fragment, which was excised from a 1\% agarose gel and eluted at $4^{\circ} \mathrm{C}$ overnight with $40 \mu \mathrm{L}$ of water. This eluted fragment was used as template for primers PARCH340f and PARCH519r. The PARCH340f contained a GC clamp on the 5' end as described by Muyzerand Ramsing (1995).

DGGE gels were made from $8 \%\left(\right.$ wt vol $\left.^{-1}\right)$ acrylamide stock solutions (acrylamide : Bis acrylamide solution 37.5:1) containing $0 \%$ and $100 \%$ denaturant $(7 \mathrm{M}$ urea and $40 \%$ [vol $\mathrm{vol}^{-1}$ ] formamide). DGGE was performed with acrylamide gels containing a linear gradient ranging from $20 \%$ to $70 \%$ denaturant ( $7 \mathrm{M}$ urea and $40 \%$ [vol vol-1] formamide) for Bacteria DNA and a gradient of $40 \%-60 \%$ for Archaea community DNA. The gels were run for $3.5 \mathrm{~h}$ at $200 \mathrm{~V}$ with a DcodeTM Universal Mutation Detection System from Bio-Rad Laboratories (Hercules, California, USA).

\subsection{Statistical analysis}

The DNA banding patterns of 16S rDNA on DGGE gels were photographed and digitized using a computer scanner. The gel images were converted into $x / y$ plots using an imageanalysis program (Scion Image; Scion Corp., Frederick, Maryland, USA), after which the peak areas associated with each DNA band were determined by peak analysis (Peakfit version 4; SPSS, Inc., Chicago, Illinois, USA). Community similarities based on peak areas and band migration distances (Retardation factor $\left[R_{f}\right]$ values; expressed as a percentage of the relative band migration distance as compared to the elution front) for the different bacterial groups (16S rDNA bands) were analyzed by performing correspondence analysis (CANOCO 4.0; Microcomputer Power, Ithaca, New York, USA). Each peak was assumed to represent a different bacterial group or species. Community similarities were graphed using ordination biplots. The effects of enrichment stage, EC, and $\mathrm{pH}$ were analyzed statistically using Monte Carlo analyses to test the null hypothesis that these variables did not significantly affect the species data.

\subsection{Bacterial identification}

The 16S rDNA bands were separated and excised from DGGE gels and placed in sterile Eppendorf tubes. Twenty microliters of sterile deionized water was placed in the tubes and stored overnight at $4^{\circ} \mathrm{C}$. Five microliters of eluted DNA was amplified by PCR as previously described, and the PCR products were verified in $1.0 \%$ agarose gels. Bands were excised and extracted using a QIAGEN gel extraction kit (QIAGEN Inc., Santa Clarita, California, USA). Purified DNA 
was then ligated into pGEM-T Easy and transformed into $E$. coli JM109 vector (Promega, Madison, Wisconsin, USA). The sequencing reaction was carried out by cycle sequencing with a SequiTherm Excel II TM Long-Read DNA sequencing kit (type LC, Epicentre, Madison, Wisconsin, USA). The purified plasmids were sequenced with a Li-COR model $400 \mathrm{~L}$ automatic sequencing system. Sequence analysis and alignments were done using the BLAST database (National Center for Biotechnology Information, 1999).

\subsection{Phylogenetic analysis}

The phylogenetic analysis of the 16S rDNA sequences was done by aligning the sequences with PILEUP (Genetics Computer Group, Madison, Wisconsin, USA), maximum likelihood analysis was performed, and confidence intervals (bootstraps) were generated using PHYLIP executables (Felsenstein, 1985, 1993). The CHECK_CHIMERA program was used to verify that none of the sequences used in this study were artifacts of PCR amplification.

\subsection{Statistical analysis of rDNA-DGGE fingerprints}

The V3 rDNA regions of Bacteria and Archaea were PCR amplified and separated by DGGE for community fingerprinting. Microbial fingerprinting of brine samples was done at two concentration levels, DNA was extracted from $0.5 \mathrm{~mL}$ of brine directly from the mine compared to a 40 -fold concentration of bacteria from brine samples by centrifugation (first and third stage of the enrichment process only).

\section{Results}

\section{$3.1 \mathrm{pH}$ and electrical conductivity}

The $\mathrm{pH}$ and EC of brine and soil samples from within the mine were highly variable even for samples at the same stage of the salt-enrichment process. The $\mathrm{pH}$ of brine samples ranged from 8.5 to 9.5 . Similarly, the $\mathrm{pH}$ of the soils ranged from 8.5 in the village soil to as high as 9.5 in leached soils taken directly from the saltern. Electrical conductivity ranged from 43 to $99 \mathrm{dS} \mathrm{m}^{-1}$ in brine samples and from 4 to $52 \mathrm{dS} \mathrm{m}^{-1}$ in the soil samples. The later stages of the enrichment process did not show expected increases in EC or $\mathrm{pH}$.

\subsection{Microbial community structure}

The V3 rDNA regions of Bacteria and Archaea showed characteristic densiometric profiles on the DGGE gel (Fig. 2). The brine samples from the first and third enrichment stage had 15 DGGE bands with identical $R_{f}$ values. There were eight unique DNA bands from the first stage brine samples and two unique DNA bands for the third stage brine samples.

Correspondence analysis supported visual observation of the gels, indicating that the measured physicochemical proper-

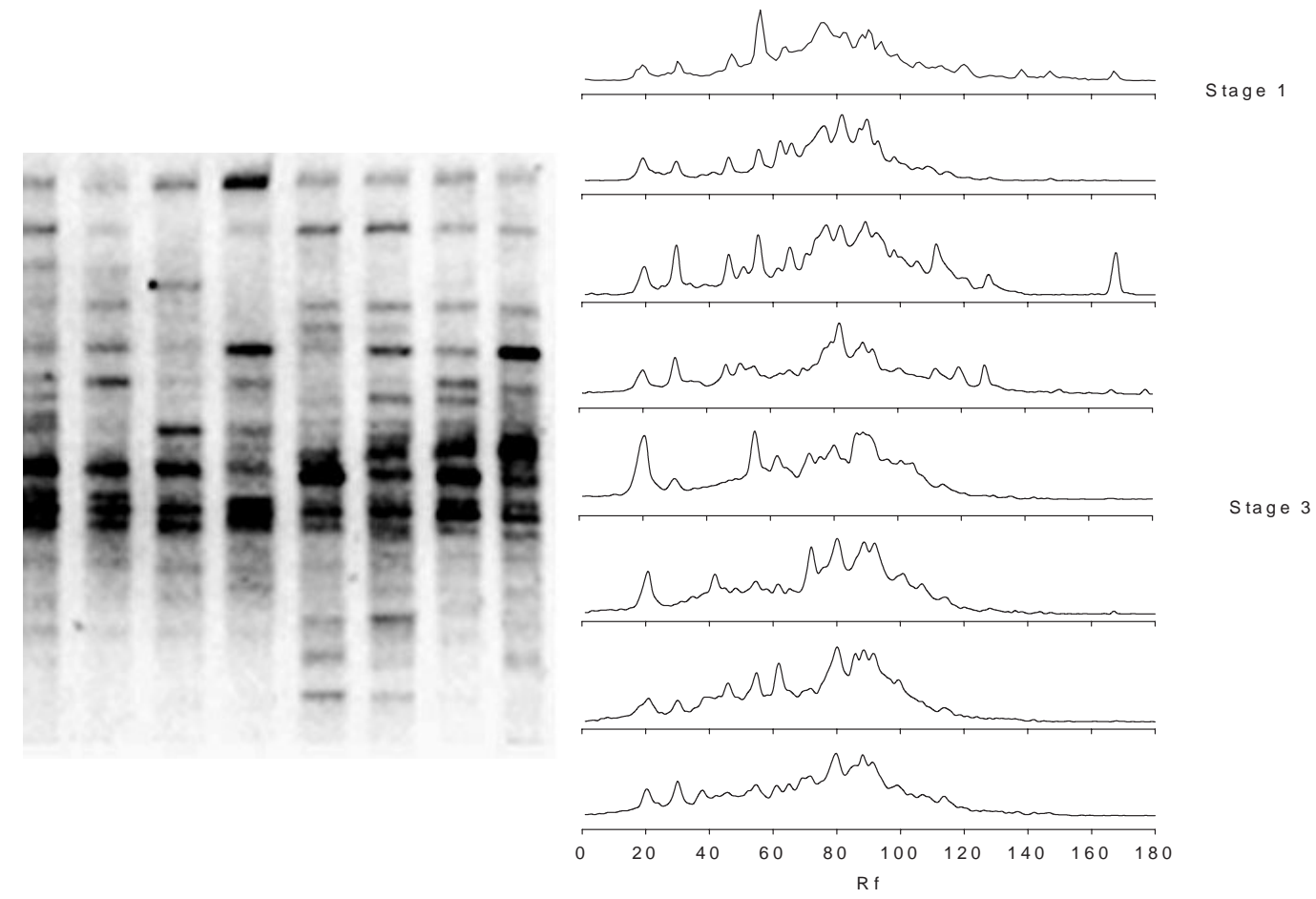

Figure 2: DGGE gel (left) and line-graph profiles of $16 \mathrm{~S}$ rDNA band patterns (right) resulting from DGGE of bacterial communities associated in the brine of the salt mine at Tegguida-n-Tessoumt, Niger.

Abbildung 2: DGGE-Gel (links) und abgeleitete Liniengraphik (rechts) der 16S-rDNA-Bandenmuster einer DGGE-Analyse der BakterienGemeinschaften in der Sole der Saline Tegguida-n-Tessoumt in Nordniger. 
ties did not influence the species data while enrichment stage did affect community structure. Ordination of the 16S rDNA band data revealed two distinct clusters in which the bacterial communities differed according to their stage in the enrichment process, such that communities that were associated with the first two stages of enrichment clustered along the positive portion of the $\mathrm{x}$-axis while the third-stage brine sample and the soil samples were much more similar (Fig. 3). None of the tested environmental variables explained a significant amount of the variation in the species data at this level of resolution. The biplot explained $72 \%$ of the variation on the $x$ - and $y$-axes. The saltern soil samples formed a distinct tight cluster compared with the cluster of pasture soil samples that were collected from outside the saltern. Although distinct, the two clusters for the soil samples were separated by less than half a standard deviation.

\subsection{Species identification}

The DGGE gel containing V3-Bacteria rDNA sequences from dilute brine samples had eight clearly distinct bands among other less intense bands. Of the eight bands that were sequenced, six were identified as representing bacteria from the gamma proteobacteria subgroup. Bands B1 and B2 were highly similar to Pseudomonas sp. PH1 (98\%), while B3 and B7 had high similarities to Pseudomonas migulae (99\%) and Pseudomonas putida (100\%), respectively, and both corresponded to Pseudomonas putida. Only three of the sequences, B5, B6, and B7, were related to what are traditionally considered halophilic bacteria and were most similar to Alkalispirillum mobilis (96\%), Halomonas sp. (97\%), and Bacillus selenitereducens (97\%), respectively. The remaining sequence, B4, was most similar to a Delta-proteobacterium $(89 \%)$. All negative controls (samples which were designed to detect contamination from analysis and sample handling) were negative as determined by negative control lanes in agarose and DGGE gels.

Phylogenetic analysis of the sequences was performed using sequences from this study and those obtained from the BLAST database search for representative bacteria from different bacterial groups. The dendrogram shown in Fig. 4 provides a visual representation of the sequence similarities.

\subsection{Identification and phylogeny estimation of Archaea}

The four soil samples from the mine had amplifiable Archaea populations, whereas all other soil and the nonconcentrated brine samples did not contain DNA from Archaea that could be amplified using the methods employed here (Fig. 5).

Of the ten bands that were selected for sequencing from the DGGE gel containing Archaea V3 region amplified sequences, two sequences from the Tegguida-n-Tessoumt (TnT) samples, TNTA2 and TNTA3, were $98 \%$ similar to Methanosarcina $s p$. VeA23, but were slightly different from each other (Fig. 6). Sequence TNT11 was $98 \%$ similar to Methanolobus taylorii, and TNTA10 was $95 \%$ similar to Natronobacterium pharaonis, a halophilic Archaeaon. The rest of the sequences had lower than $95 \%$ similarity to any known Archaea.

The dendogram produced by maximum-likelihood analysis clustered the sequences into five separate groups of Archaea, four of which were methanogenic; MethanoculleusMethanogenium cluster (2 sequences), Methanolobus (3 sequences), Methanobacterium (2 sequences), and

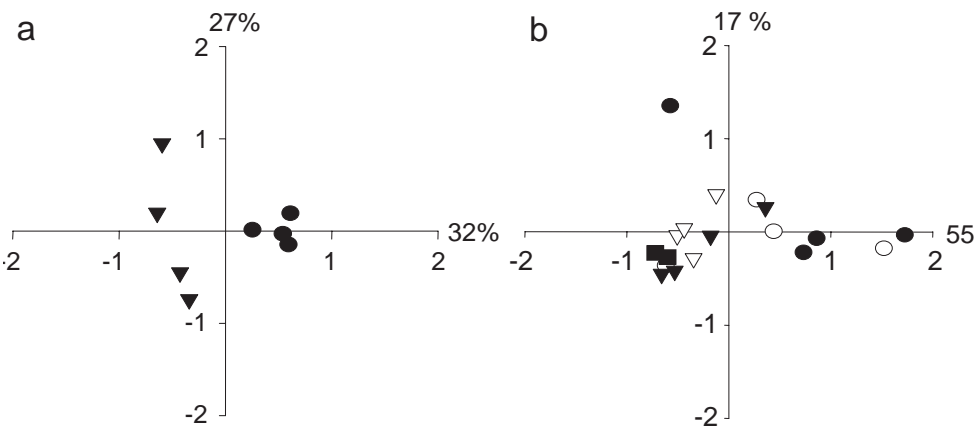

Figure 3: Comparison of microbial-community structures based on correspondence analysis of the DNA banding patterns generated by PCRDGGE of $16 S$ rDNA sequences from different samples taken at Teguidda-n-Tessoumt, Niger.

(a) Ordination diagram of Bacteria communities associated with brine concentrated 40 -fold, generated by correspondence analysis of $16 \mathrm{~S}$ rDNA profiles of individual brine samples; the treatment stage of the brine is represented at the $x$-axis. Symbols represent data from the first $(\mathbf{\nabla})$ and the third $(\bullet)$ enrichment step of the brine. (b) Ordination diagram of Bacteria communities associated with different brine and soil samples generated by correspondence analysis of their $16 \mathrm{~S}$ rDNA profiles. Symbols represent data from brine of the first $(\boldsymbol{\nabla})$ and third $(\boldsymbol{\bullet})$ enrichment step and from mine $(\bigcirc)$, village $(\mathbf{\square})$, and grassland $(\nabla)$ soils, respectively.

Abbildung 3: Vergleich der Strukturen von Mikrobengemeinschaften in Teguidda-n-Tessoumt (Niger), die aus Korrespondenzanalysen der DNA-Bandenmuster einer PCR-DGGE von 16S-rDNA-Sequenzen verschiedener Proben abgeleitet wurden.

(a) Ordinatendiagramm der Bakterienpopulationen in der 40-fach konzentrierten Sole, erstellt aus einer Korrepondenzanalyse der 16S-rDNAProfile einzelner Soleproben. Auf der X-Ache ist der Aufbereitungsgrad der Sole dargestellt, wobei die Symbole für Daten aus dem ersten ( $\mathbf{\nabla})$ und dem dritten (@) Anreicherungsschritt stehen. (b) Ordinatendiagramm der Bakterienpopulationen verschiedener Sole- und Bodenproben erstellt aus einer Korrepondenzanalyse der jeweiligen 16S-rDNA-Profile. Die Symbole stehen für Daten aus dem ersten $(\boldsymbol{\nabla})$ und dem dritten (๑) Anreicherungsschritt der Sole sowie für Daten aus Salinenböden ( $)$, Dorfböden ( $\square$ ) und Grassteppenböden $(\nabla)$ am Standort. 


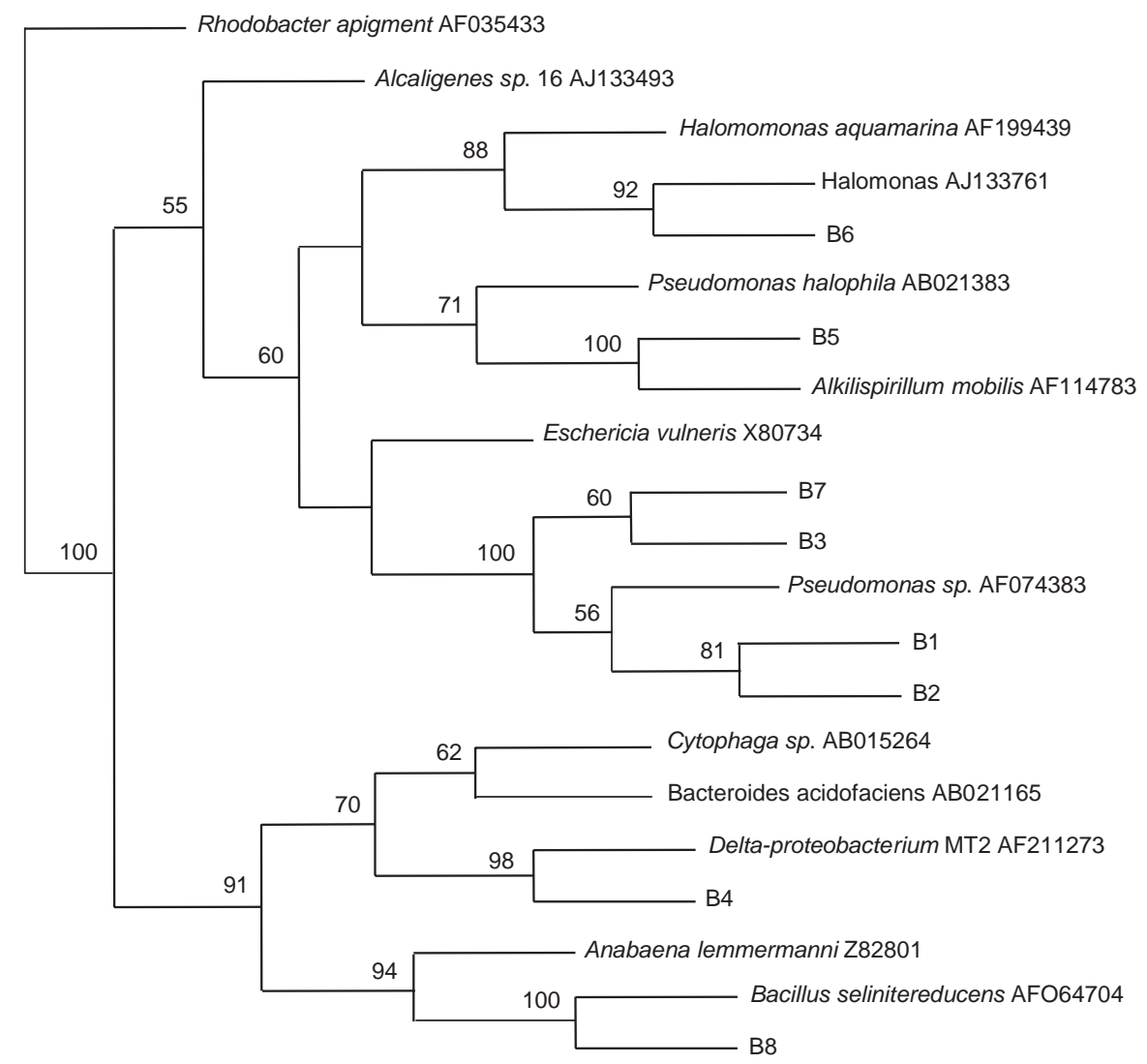

Figure 4: Results of a maximum-likelihood analysis of Bacteria V3-region 16S rDNA clones using 150 alignable positions. Numbers at the nodes represent the percentage of 500 bootstrap replications that support the branching pattern away from a node. Accession numbers for reference sequences are also shown.

Abbildung 4: Ergebnis der „MaximumLikelyhood"-Analyse der Bakterienklone der V3-Region der 16S rDNA unter Verwendung von 150 abgleichbaren Positionen. Werte an den Knoten geben den Prozentsatz von 500 „bootstrap“-Wiederholungen an, der dem Verzweigungsmuster vom Knoten aus entspricht. Identifikationsnummern der Referenzsequenzen sind ebenfalls angegeben.
Methanosarcina (2 sequences; Fig. 6). Only one sequence clustered with the halophilic Natronobacterium pharaonis.

\section{Discussion}

Based on the long history of continuous use and deliberate manipulation through manure additions and sequential saltenrichment steps, the Teguidda-n-Tessoumt salt mine provides an intriguing opportunity to study microbial biodiversity. Given the continental desert climate, the ponds provide a relatively harsh saline environment which is regularly subjected to eutrophy by the addition of animal manure containing diverse heterotrophic bacteria. These come from both resident and foreign livestock herds and caravans that stop for a few days after having traveled over large distances. Animal foraging results in the intake of the diverse microflora that are associated with plant feeds (Morris et al., 1998). Given the regular inoculation of the brine with manure, the salt ponds of Tegguida-n-Tessoumt should thus contain a unique community of salt-tolerant bacteria from large areas of the surrounding Saharan and Sahelian environments.

As much of the microbial diversity in many environmental samples is unculturable (Torsvik et al., 1990; Richaume et al., 1993), community fingerprinting using DGGE provides an alternative method for determination of the dominant microbial community. Judging upon the results of this method, the saltern's brine appeared to have a fairly simple but highly structured bacterial community. There were a total of eight unique bands corresponding to groups or species of bacteria in samples of the first enrichment stage that were lost from the dominant community over the course of the salt enrichment process and two new species that were found only in the third enrichment-stage samples. Statistical analysis of species data showed that the enrichment stage of the brine explained $37 \%$ of the variation in the species data. One possible explanation for this is that within a time period of 4-6 $\mathrm{h}$ (the time it takes for desiccation in the ponds), the solution goes from a salty brine of approximately $5 \%-10 \%$ salt and $\mathrm{pH}$ of 9 to a stage where the brine is saturated with salt and the dry salts are finally precipitated.

Many of the species of Archaea and Eubacteria that were identified from the mine had high similarities within the V3 region to sequences of previously described bacteria, suggesting that many of the dominant bacteria detected by PCR/ DGGE from the salt mine were possibly not endemic to the mine and may have a wider distribution. Similar results for alkaline subsurface and alkaline-saline surface waters have been reported previously (Duckworth et al., 1996; Fry et al., 1997). The low level of divergence exhibited by some of the sequences from known organisms in the BLAST database within what is a highly variable region of the $16 \mathrm{~S}$ rDNA is supportive of the matches, but the small fragment length used in this study does not permit drawing stronger conclusions on the level of divergence that may have occurred in members of the Archaea and Bacteria communities from known relatives (Ward et al., 1990; Muyzer and Ramsing, 1995; Fry et al., 1997). 

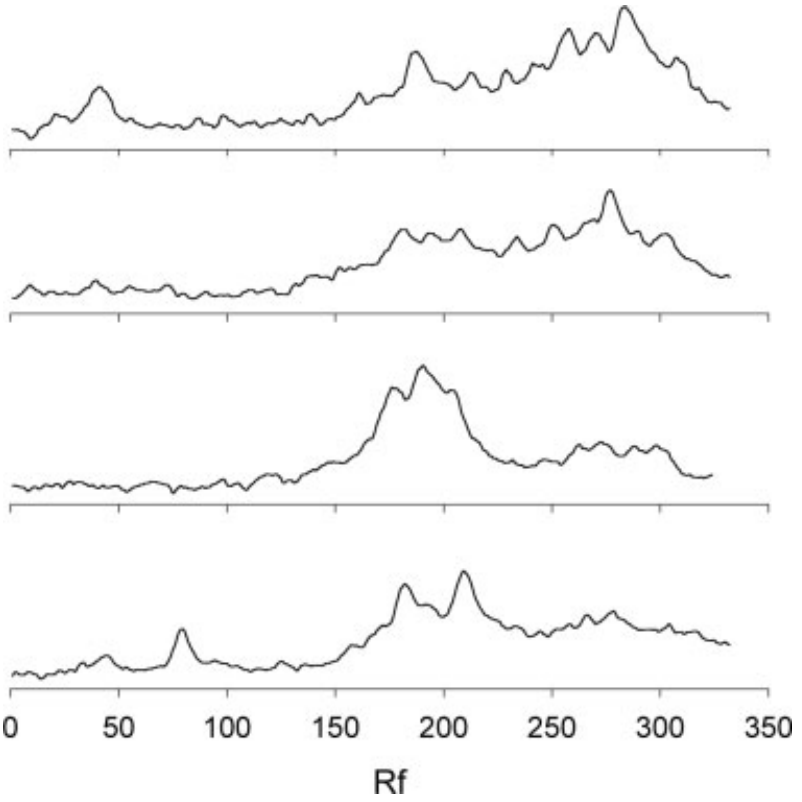

Figure 5: Line-graph profiles of 16S rDNA band patterns resulting from DGGE of Archaea communities associated with soil from the salt mine at Tegguida-n-Tessoumt, Niger. Each peak represents a DNA band position, with the peak size and area representing the relative predominance of the species that are shown by the DNA band. The spectrogram demonstrates the relative complexity (numbers of bands) associated with the microbial community from the four soils.

Abbildung 5: Liniengraphik der 16S-rDNA-Bandenmuster einer DGGE-Analyse der Archaea-Gemeinschaften in Böden der Saline Tegguida-n-Teseroumt in Nordniger. Jede Spitze enspricht einer DNA-Bandenposition. Spitzenhöhe- und -fläche geben die relative Häufigkeit der dieser Bandenposition entsprechenden Art an. Das Spektrogramm zeigt die relative Komplexizität (Anzahl der Banden) der mikrobiellen Gemeinschaften der vier Böden.
Recent studies on the natural distribution of Archaea using 16S rRNA methods have changed the view of Archaea as existing solely in extreme environments. Archaea populations have been identified in fresh (Ovreas et al., 1997; Pernthaler et al., 1998) and salt (Delong, 1992; Massana et al., 1997; Munson et al., 1997) waters, in very hot waters (Ferris et al., 1996; Takai and Sako, 1999), and in soils from different climates (Bintrim et al., 1997; Borneman and Triplett, 1997). Methanogenic archaea have also been found in anaerobic sediments (Falz et al., 1999; McDonald et al., 1999). The absence of an amplifiable Archaea community in the grassland and village soils suggests that an enrichment of this community occurred during the salt-extraction process. The saturation of the heavy soils in the mine, addition of organic substrate, and subsequent anaerobic conditions are probably the most important environmental factors leading to the selective enrichment of Archaea community in the saltern system.

In their phylogenetic diversity studies of soda lake mud or water samples of the Kenyan-Tanzanian Rift Valley, Duckworth et al. (1996) were able to culture Pseudomonas, Bacillus, and Halomonas similar to some of the predominant bacteria in the present study, but did not find any methanogenic Archaea. Although we did not attempt to culture bacteria from our samples, the fact that similar bacteria had been previously cultured from saline sodic waters indicates potential culturability. The advantage of DGGE is the ability to generate fingerprints of dominant community structures as they occur in the natural environment.

Pseudomonas have been found to grow in marine environments, alkaline sodic ponds, and also include a few halophilic strains, but in general are considered to be opportunistic bacteria that prefer fastidious growth conditions (Duckworth et

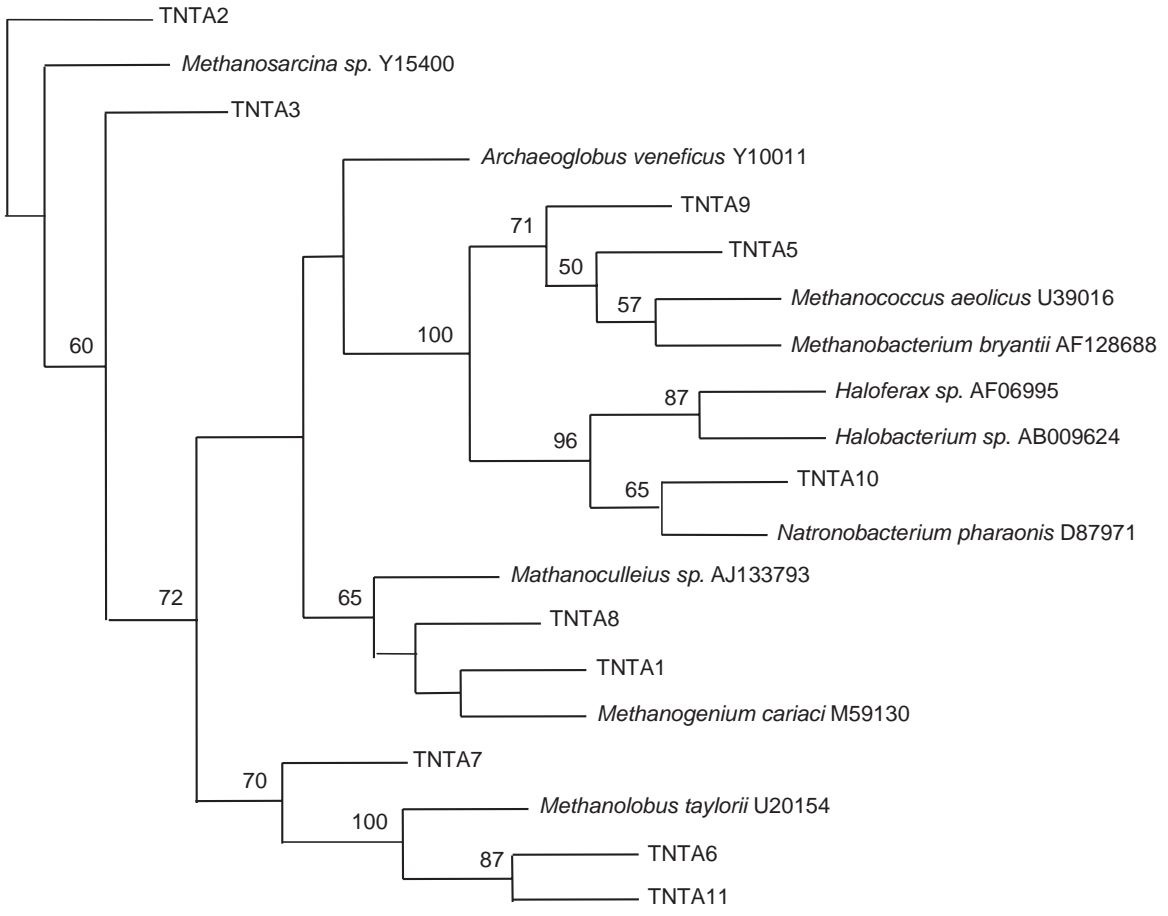

Figure 6: Results of a maximum-likelihood analysis of Archaea V3 region 16S rDNA clones from soil of the salt mine at Tegguida-n-Tessoumt, Niger using 150 alignable positions. Numbers at the nodes represent the percentage of 500 bootstrap replications that support the branching pattern away from a node. Accession numbers for reference sequences are also shown.

Abbildung 6: Ergebnis der „MaximumLikelyhood"-Analyse der Archaea-Klone der V3-Region der 16S rDNA unter Verwendung von 150 abgleichbaren Positionen. Werte an den Knoten geben den Prozentsatz von 500 „bootstrap“-Wiederholungen an, der dem Verzweigungsmuster vom Knoten aus entspricht. Identifikationsnummern der Referenzsequenzen sind ebenfalls angegeben. 
al., 1996; Fry et al., 1997). Pseudomonas-like bacteria have been found in alkaline sodic waters; however, it remained unclear whether they constituted a dominant proportion of the community from which they were cultured. The relatively high $\mathrm{pH}$ and salinity in the evaporation ponds would also seem conducive to the growth of halophilic and alkaliphilic bacteria such as Bacillus sp. Although these groups were present, they were represented in the DGGE gel by only one DNA band in the brine samples obtained from the first brine-enrichment pond.

\section{Conclusions}

The combination of human activities and natural events resulted in unique microbial-community assemblages at the Tegguida-n-Tessoumt saltern. Apparently many groups of organisms have been mixed allowing for genetic exchange, adaptation to saline-alkaline conditions and acquisition of traits for tolerance of high-stress environments such as the mine itself or the rumen and human gut. Not only are there many routes for bacteria into the mine environment by human contact, soil, water, and manure, but there are also several means of dispersal. Salt transported by caravans and fed to livestock will likely reach a wide distribution through market systems and animal herding. From a microbiological perspective, the final result of the salt production activity is thus a system in which many different cosmopolitan bacteria have been brought together in a highly selective environment.

\section{References}

Ajayi, J. F. A., Crowder, M. (1987): History of West Africa. 2nd ed., Longman, London, pp. 658-660.

Bintrim, S. B., Donohue, T. J., Handelsman, J., Roberts, G. P., Goodman, R. M. (1997): Molecular phylogeny of Archaea from soil. Proc. Natl. Acad. Sci. 94, 277-282.

Borneman, J., Triplett, E. W. (1997): Molecular microbial diversity in soils from Easter Amazonia: evidence for unusual microorganisms and microbial population shifts associated with deforestation. Appl. Environ. Microbiol. 63, 2647-2653.

Buerkert, A., Hiernaux, P. (1998): Nutrients in the West African Sudano-Sahelian zone: losses, transfers and role of external inputs. J. Plant Nutr. Soil Sci. 161, 365-383.

Buerkert, A., Mahler, F., Marschner, H. (1996): Soil productivity management and plant growth in the Sahel: Potential of an aerial monitoring technique. Plant and Soil 180, 29-38.

Delong, E. F. (1992): Archaea in coastal marine environments. Proc. Natl. Acad. Sci. USA 89, 5685-5689.

Duckworth, A. W., Grant, W. D., Jones, B. E., van Steenbergen, R. (1996): Phylogenetic diversity of soda lake alkaliphiles. FEMS Microbiol. Ecol. 19, 181-191.

Falz, K. Z., Holliger, C., Grossskopf, R., Liesack, W., Noshevnikova, A. N., Muller, B., Wehrli, B., Hahn, D. (1999): Vertical distribution of methanogens in the anoxic sediment of Rotsee (Switzerland). Appl. Environ. Microbiol. 65, 2402-2408.

Felsenstein, J. (1985): Confidence limits on phylogenies: an approach using the bootstrap. Evolution 19, 783-791.
Felsenstein, J. (1993): PHYLIP. University of Washington, Seattle.

Ferris, M. J., Muyzer, G., Ward, D. M. (1996): Denaturing gradient gel electrophoresis profiles of 16S rRNA-defined populations inhabiting a hot spring microbial mat community. Appl. Environ. Microbiol. 62, 340-346.

Fry, N. K., Fredrickson, J. K., Fishbain, S., Wagner, M., Stahl, D. A. (1997): Population structure of microbial communities associated with two deep, anaerobic, alkaline aquifers. Appl. Environ. Microbiol. 63, 1498-1504.

Massana, R., Murray, A. E., Preston, C. M., DeLong, E. F. (1997): Vertical distribution and phylogenetic characterization of marine planktonic Archaea in the Santa Barbara Channel. Appl. Environ. Microbiol. 63, 50-56.

McDonald, I. R., Upton, M., Hall, G., Pickup, R. W., Edwards, C., Saunders, J. R., Rithcie, D. A., Murrel, J. C. (1999): Molecular ecological analysis of methanogens and methanotrophs in blanket bog peat. Microbial Ecology 38, 225-233.

Morris, C. E., Monier, J. M., Jacque, M. A. (1998): A technique to quantify the population size and composition of the biofilm component in communities of bacteria in the phyllosphere. Appl. Environ. Microbiol. 64, 4789-4795.

Munson, M. A., Nedwell, D. B., Embley, T. M. (1997): Phylogenetic diversity of Archaea in sediment samples from a coastal salt marsh. Appl. Environ. Microbiol. 63, 4729-4733.

Muyzer, G., Ramsing, N. B. (1995): Molecular methods to study organization of microbial communities. Water Sci. Technol. 32, 1-9.

National Center for Biotechnology Information (1999): BLAST database. 5 November 1999, revision date. http://www.ncbi.nlm. nih.gov (date accessed: February 28, 2000).

Ovreas, L., Torsvik, V. (1998): Microbial diversity and community structure in two different agricultural soil communities. Microbial Ecology 36, 303-315.

Ovreas, L., Forney, L., Daae, F. L., Torsvik, V. (1997): Distribution of bacterioplankton in meromictic lake Saelenvannet, as determined by denaturing gradient gel electrophoresis of PCR-amplified gene fragments coding for 16s rRNA. Appl. Environ. Microbiol. 63, 3367-3373.

Pernthaler, J., Glockner, F., Unterholzner, S., Alfreider, A., Psenner, R., Amann, R. (1998): Seasonal community and population dynamics of pelagic bacteria and archaea in a high mountain lake. Appl. Environ. Microbiol. 64, 4299-4306.

Richaume, A., Steinberg, C., Jocteur-Monrozier, L., Faurie, G. (1993): Differences between direct and indirect enumeration of soil bacteria: the influence of soil structure and cell location. Soil Biol. Biochem. 25, 641-643.

Takai, K., Sako, Y. (1999): A molecular view of archaeal diversity in marine and terestrial hot water environments. FEMS Microbiol. Ecol. 28, 177-188.

Torsvik, V., Goksoyr, J., Daae, F. L. (1990): High diversity in DNA of soil bacteria. Appl. Environ. Microbiol. 56, 782-787.

Ward, D. M., Weller, R., Bateson, M. M. (1990): 16S rRNA sequences reveal numerous uncultured microorganisms in a natural community. Nature 345, 63-65.

Yang, C.-H., Crowley, D. E. (2000): Rhizosphere microbial community structure in relation to root location and plant iron nutrition status. Appl. Environ. Microbiol. 66, 345-351. 